\title{
Correction to: Evolutionary biogeography of the centipede genus Ethmostigmus from Peninsular India: testing an ancient vicariance hypothesis for Old World tropical diversity
}

\author{
Jahnavi Joshi* and Gregory D. Edgecombe
}

Correction to: BMC Evol Biol

https://doi.org/10.1186/s12862-019-1367-6

Following publication of the original article [1], the authors notified us of an error in the Results section of the Abstract. The original article has been corrected.

- Originally, the first phrase of the Results section was published as:

Divergence time estimates suggest that Ethmostigmus began diversifying in the Early Cretaceous, 125.4 ( \pm 25$)$ million years ago (Ma), its early biogeographic history shaped by vicariance. Members of Ethmostigmus in PIP form a monophyletic group that underwent endemic radiation in the Late Cretaceous, $100( \pm 25) \mathrm{Ma}$.

- The phrase was corrected to:

Divergence time estimates suggest that Ethmostigmus began diversifying in the Late Cretaceous, $99( \pm 25)$ million years ago $(\mathrm{Ma})$, its early biogeographic history shaped by vicariance. Members of Ethmostigmus in PIP form a monophyletic group that underwent endemic radiation in the Late Cretaceous, $72( \pm 25)$ Ma.

Received: 8 February 2019 Accepted: 8 February 2019

Published online: 14 February 2019

\section{Reference}

1. Joshi J, Edgecombe GD. Evolutionary biogeography of the centipede genus

Ethmostigmus from Peninsular India: testing an ancient vicariance

hypothesis for Old World tropical diversity. BMC Evol Biol. 2019;19:41.

https://doi.org/10.1186/s12862-019-1367-6.

\footnotetext{
*Correspondence: jahnavi.joshi@nhm.ac.uk; jj.jahnavi@gmail.com

The Natural History Museum, Cromwell Road, London SW7 5BD, UK
}

(c) The Author(s). 2019 Open Access This article is distributed under the terms of the Creative Commons Attribution 4.0 International License (http://creativecommons.org/licenses/by/4.0/), which permits unrestricted use, distribution, and reproduction in any medium, provided you give appropriate credit to the original author(s) and the source, provide a link to the Creative Commons license, and indicate if changes were made. The Creative Commons Public Domain Dedication waiver (http://creativecommons.org/publicdomain/zero/1.0/) applies to the data made available in this article, unless otherwise stated. 